Огляди літератури, оригінальні дослідження, погляд на проблему, випадок з практики, короткі повідомлення УДК 617.731/.735-091.8-02:617.723-002-085.214.2]-092.9

DOI 10.11603/1811-2471.2020.v.i3.11586

\title{
УЛЬТРАСТРУКТУРНИЙ СТАН СІТКІВКИ ТА ЗОРОВОГО НЕРВА В ЕКСПЕРИМЕНТІ НЕІНФЕКЦІЙНОГО ПЕРЕДНЬОГО ТА СЕРЕДНЬОГО УВЕЇТУ НА КРОЛЯХ БЕЗ ЛІКУВАННЯ ТА ПРИ ВИКОРИСТАННІ НЕЙРОПРОТЕКТОРА
}

\author{
๑О. В. Зборовська, Н. І. Молчанюк, О. Е. Дорохова, І. С. Горянова
}

ДУ «Інститут очних хвороб і тканинної терапії імені В. П. Філатова НАМН України», Одеса

PЕЗЮМЕ. В літературі відсутні відомості про нейродегенеративні процеси в сітківці і зоровому нерві при передніх і середніх увеїтах.

Мета - провести порівняльне ультраструктурне дослідження зорових нервів, сітчастої і судинної оболонок ока при неінфекційному передньому і середньому увеїтах в експерименті.

Матеріал і методи. Експеримент проведений на 4 кролях: 1 група - 2 кролі (без лікування), 2 група - 2 кролі (використовувався нейропротектор). Вивчали ультраструктуру хоріокапілярів (ХК), сітківки і зорових нервів (ЗН) кролів через 10 діб.

Результати. В 1 групі в ЗН виявили глибокі деструктивні процеси в нервових волокнах, мієліновій оболонці, в гліальних клітинах із руйнуванням їх плазмолем, а також вогнищевий міжклітинний набряк. У судинній і сітчастій оболонках виявили гідропічну дегенерацію ендотеліальних клітин ХК і клітин сітківки, особливо ПЕС, а також міжклітинний набряк в ділянці ФК. У 2 групі в ЗН деформація мієлінових облонок, набряк в аксоплазмі трапляються в меншій мірі і в меншій кількості НВ. В аксоплазмі більшості НВ мітохондрії та інші органели мали нормальну ультраструктуру. Найбільш збереженими виявилися НВ дрібного калібру. В шарі ХК переважали ЄК з ознаками компенсаційно-відновних процесів. Поряд з цим частина ЄК XК залишалися в стані набряку.

Висновки. Передній і середній неінфекційний увеїт, який моделювали за допомогою кінської сироватки, викликає нейродегенеративні зміни в сітчастій оболонці і ЗН, а при використанні нейропротектора (протягом 10 днів) явища нейродегенерації були виражені в меншій мірі.

КлючовІ СлОВА: неінфекційний увеїт; нейродегенерація; нейропротектор.

Вступ. Неінфекційні автоімунні увеїти - це значна група увеїтів (близько $40 \%$ ), що виникають при системних захворюваннях організму (анкілозивний спондилоартрит, хвороба Бехчета, саркоїдоз, запальні захворювання кишечника, псоріатичний артрит тощо). Дебют увеїту найчастіше виникає у віці від 32 до 45 років $[1,19,20,25,29,31]$. Увеїт $\epsilon$ п'ятою за частотою причиною втрати зору в жителів розвинених країн світу і може призводити до їх інвалідизації, а при тяжких формах увеїту - і до сліпоти (до 20 \%) [22].

При тяжкому перебігу увеїту в патологічний процес можуть залучатися зоровий нерв (ЗН) та макулярна ділянка сітківки, з розвитком ускладнень - набряку диска 3Н і макулярного набряку. Дані різних авторів мають відхилення щодо відсоткового співвідношення ускладнень. A. Rodriguez et al. (1994) пишуть про тяжкі загрозливі для зору ускладнення, такі як папіліт в 82,7 \% випадків і кістозний макулярний набряк в 37,9 \% випадків [28]. H. Uy et al. (2001) виявили кістозний макулярний набряк у 13,4 \% хворих на увеїт [33]. А. А. Годзенко зі співавт. (2014) говорять про пошкодження різних структур ока зі зниженням зорових функцій майже у $1 / 3$ пацієнтів [2].

Однак трапляються повідомлення й про те, що в переважній більшості випадків переднього увеїту, навіть без клінічно значимого макулярного набряку, наявна асиметрія макулярного рельє- фу, порівняно зі здоровим оком [32]. Ці зміни зберігаються ще довго після стихання запалення. А потовщення макули в 70 \% випадків $\epsilon$ швидше правилом, ніж винятком [35].

У літературі $\epsilon$ дані щодо стану сітківки і зорового нерва при експериментальних увеоретинітах та відсутні відомості про нейродегенеративні процеси в сітківці і зоровому нерві при експериментальних передніх та середніх увеїтах. Це спонукало нас дослідити, чи відбуваються процеси нейродегенерації як ускладнення передніх та середніх увеїтів.

Одним із найбільш відомих та вивчених у світі нейропротекторів $\epsilon$ цитиколін. В офтальмології його використовують при глаукомній [9] та інших оптиконейропатіях [6], при частковій атрофії зорового нерва [7] та при нейротоксичних ураженнях зорових нервів $[26,27]$.

Мета - провести порівняльне ультраструктурне дослідження зорового нерва (3Н), сітчастої і судинної оболонок ока при неінфекційному передньому і середньому увеїтах в експерименті: без застосування нейропротекторної терапії (цитиколіном) та з її використанням на ранніх термінах захворювання.

Матеріал і методи дослідження. Експеримент було проведено на 4 кролях породи шиншила, вагою від 2,5 до 3 кг, яких поділили на 2 групи: 1 група (2 кролі) - тварини, яким моделювали ав- 
Огляди літератури, оригінальні дослідження, погляд на проблему, випадок з практики, короткі повідомлення тоімунний увеїт, 2 група (2 кролі) - тварини, які на фоні модельованого увеїту отримували цитиколін. Увеїт моделювали за методикою, описанною Дороховою О. Е. зі співавторами: на правих очах шляхом введення стерильної нормальної кінської сироватки в крайову вену вуха в кількості 1,0 мл протягом 5 днів з проміжками в 24 години. Через 10 днів вводили провокуючу дозу - 0,1 мл нормальної кінської сироватки інтравітреально в праве око [16]. Через добу після введення розвивався запальний процес у судинній оболонці - передній та середній увеїт. Кролям цієї групи щоденно вводили цитиколін по 0,2 мл внутрішньом' язово протягом всього терміну спостереження. Клінічний перебіг увеїту у тварин обох груп контролювався за допомогою офтальмоскопії та біомікроскопії.

Роботу з експериментальними тваринами та виведення їх з експерименту здійснювали згідно з правилами «Європейської конвенції про захист хребетних тварин, які використовуються для експериментальних та інших наукових цілей» (Страсбург, 1986) та з Законом України № 3447-IV «Про захист тварин від жорстокого поводження».

Методом електронної мікроскопії вивчали ультраструктуру хоріокапілярів (ХK) та сітківки центральної зони і ретробульбарної частини ЗН кролів через 10 діб після введення провокуючої дози. Для дослідження шматочки тканин фіксували в 2,5 \% розчині глютаральдегіду на фосфатному буфері при значенні рН 7,4 з дофіксацією 1 \% розчином осмієвої кислоти при такому ж рН буферно-

го розчину. Потім зразки зневоднювали у спиртах висхідної концентрації. Просочення тканин та їх полімеризацію проводили в суміші епоксидних смол епон-аралдит. Контрастування ультратонких зрізів проводили за класичною методикою Reynolds. Вивчали і фотографували зразки тканин в електронному мікроскопі ПЕМ-100-01.

Результати й обговорення. Через 10 діб після моделювання увеїту в шарі хоріокапілярів (XK) судинної оболонки більшість ендотеліальних клітин (ЕК) набували ознак гідропічної дистрофії. Фенестри на стоншених ділянках ЕК визначались погано. Просвіти ХК мали підвищену електронну щільність, у них виявлялись поодинокі деструктивно змінені еритроцити та лейкоцити. У частині ЕК спостерігалось збільшення кількості внутрішньоклітинних органел, що може вказувати на компенсаторну активацію метаболічних процесів.

У сітківці найпошкодженішими виявились клітини ПЕС. У цьому шарі частина клітин була повністю зруйнована, інша мала різний ступінь деструкції органел та плазмолеми. Найглибші зміни відбувалися в апікальній ділянці, де спостерігалося тотальне руйнування мікроворсинок. Виявлялися відсутність базальних складок, пошкодження пухирців гладкої ендоплазматичної сітки (ГлЕС) та цистерн гранулярної ендоплазматичної сітки (ГЕС), порушення мітохондрій, яке полягало в деструкції крист та в набряку внутрішньомітохондріального матриксу. Деякі крупні мітохондрії мали зруйновану зовнішню мембрану (рис. 1).

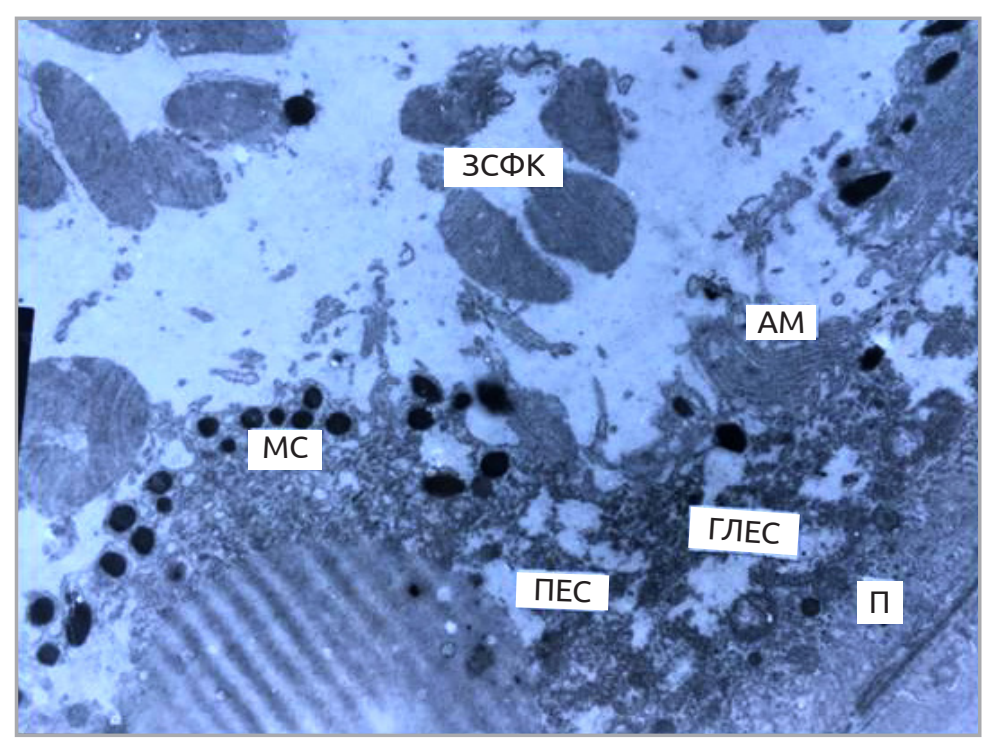

Рис. 1. Ультраструктура сітківки кроля через 10 діб після моделювання увеїту.

Пошкодження апікального та базального рельєфу клітин пігментного епітелію. Деструкція їх цитоплазматичних структур. Міжрецепторний набряк. Фрагментація і деструкція зовнішніх сегментів фоторецепторів. Електронна мікрофотографія: $\times 5000$.

Примітка. ПЕС - пігментний епітелій сітківки; ЗСФК - зовнішні сегменти фоторецепторних клітин; П - полісоми; ГлЕС - гладка ендоплазматична сітка; АМ - апікальні мікроворсинки; МС - меланосоми. 
Огляди літератури, оригінальні дослідження, погляд на проблему, випадок з практики, короткі повідомлення

В окремих клітинах ПЕС визначалась дещо збільшена кількість мітохондрій та полісом, що відображало посилення у них білковосинтезувальної та енергетичної функцій, спрямованих на внутрішньоклітинні репаративні процеси.

Цитоархітектоніка у шарі зовнішніх сегментів фоторецепторних клітин (ЗСФК) на окремих ділянках виявилася грубо порушеною за рахунок значного міжрецепторного набряку. В міжклітинному просторі спостерігали фрагменти відокремлених ЗСФК та частини зруйнованих клітин ПЕС (рис. 1). Мембранні диски ЗСФК у цих зонах також були значною мірою пошкоджені. У внутрішніх сегментах фоторецепторних клітин (ВСФК) спостерігали помірний набряк мембранних органел та цитозолю. Ядра ФК були без видимих змін. У глибоких шарах сітківки слабкі деструктивні зміни мали осередковий характер.

Дослідження зорового нерва (3Н) у більшості нервових волокон (НВ) виявило набряк аксоплазми та нечіткість структури нейротрубочок та нейрофіламентів, патологію мітохондрій, яка полягала в набряку внутрішньомітохондріального матриксу та повній або частковій деструкції їх крист. Спостерігалась деформація мієлінових облонок з розшаруванням ламел (рис. 2). В окремих НВ крупного калібру мієлінова оболонка була майже повністю зруйнована. Крім того, зустрічались осередки міжклітинного набряку та безструктурні ділянки. Серед гліальних клітин деякі мали ознаки гідропічної дистрофії - розширені цистерни ГЕС та вакуолізовані мітохондрії, інші були з елементами компенсаційно-відновних процесів.

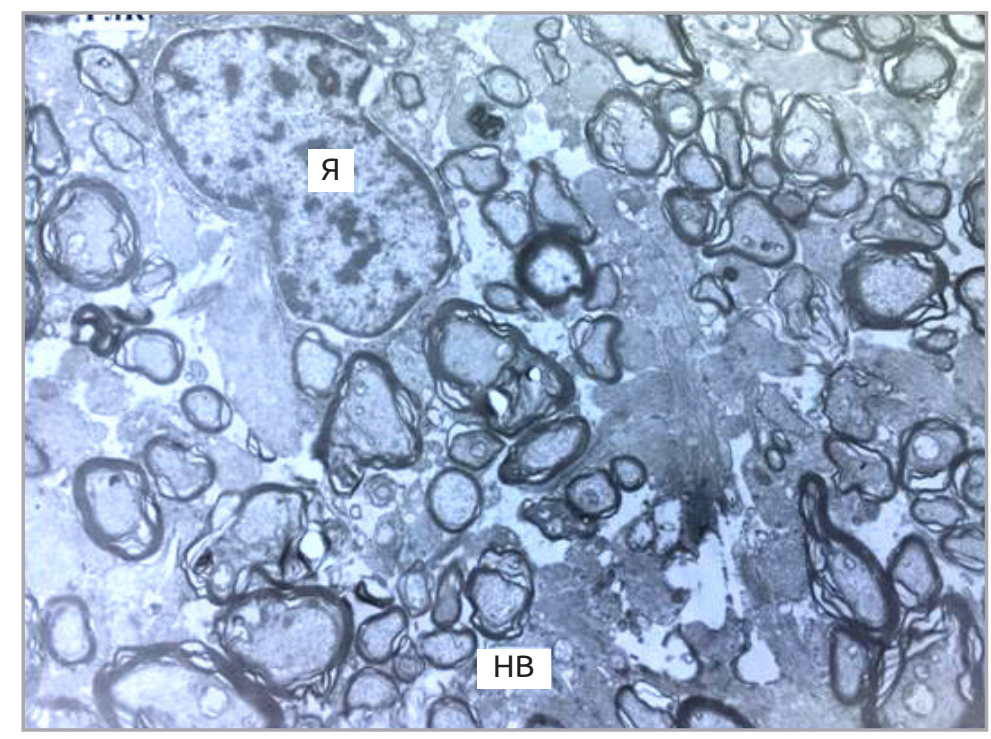

Рис. 2. Ультраструктура зорового нерва кроля через 10 діб після моделювання увеїту.

Осередкове пошкодження відростків гліальних клітин, деформація і розшарування мієлінових оболонок нервових волокон. Електронна мікрофотографія: $\times 4000$.

Примітка. НВ - нервові волокна, ГлК - гліальна клітина, Я - ядро.

У кролів, які протягом 10 днів отримували нейропротектор, у шарі ХК переважали ЕК із ознаками компенсаційно-відновних процесів: їх крупні витягнуті ядра мали звивисту каріолему, цистерни ГЕС були помірно розширеними із тонкозернистим вмістом, спостерігались скупчення полісом. Поряд з цим частина ЕК ХК залишалась у стані набряку.

У шарі ПЕС спостерігалася досить гетероморфна картина. Частина клітин структурно була близькою до норми, інша - мала ознаки гідропічної дистрофії, хоч і менш вираженої, ніж у клітинах ПЕС попередньої групи. У частині клітин спостерігали ознаки активації їх метаболічної діяльності (рис. 3).
В ділянці ФК зберігались елементи міжклітинного набряку, визначалася локальна деструкція мембран дисків ЗСФК, патологія мітохондрій у ВСФК; незначне просвітлення цитоплазми та підвищена кількість у ній полісом. В інших шарах сітківки осередково спостерігались елементи внутрішньоклітинного набряку, проте в більшості клітин структура була збереженою з посиленням ознак білкового синтезу, направленого на внутрішньоклітинні потреби за рахунок великої кількості полісом.

У ЗН після застосування нейропротектора деформація мієлінових облонок та явища набряку в аксоплазмі траплялися в меншій мірі й у меншій кількості НВ. В аксоплазмі більшості НВ мітохон- 
Огляди літератури, оригінальні дослідження, погляд на проблему, випадок з практики, короткі повідомлення дрії та інші органели мали нормальну ультраструктуру. Найбільш збереженими виявлялись НВ дрібного калібру. Більшість гліальних клітин мали ознаки посилених компенсаційно-відновних процесів. Їх ядра були переважно з дифузним хроматином, одним або двома периферійно розташова-

ними ядерцями, звивистою каріолемою. В цитоплазмі виявлялось багато полісом, в окремих розширених цистернах ГЕС - скупчення фібрилярних структур. Усе це відображало посилення білковосинтезувальних процесів як на внутрішньоклітинні, так і на позаклітинні потреби (рис. 4).

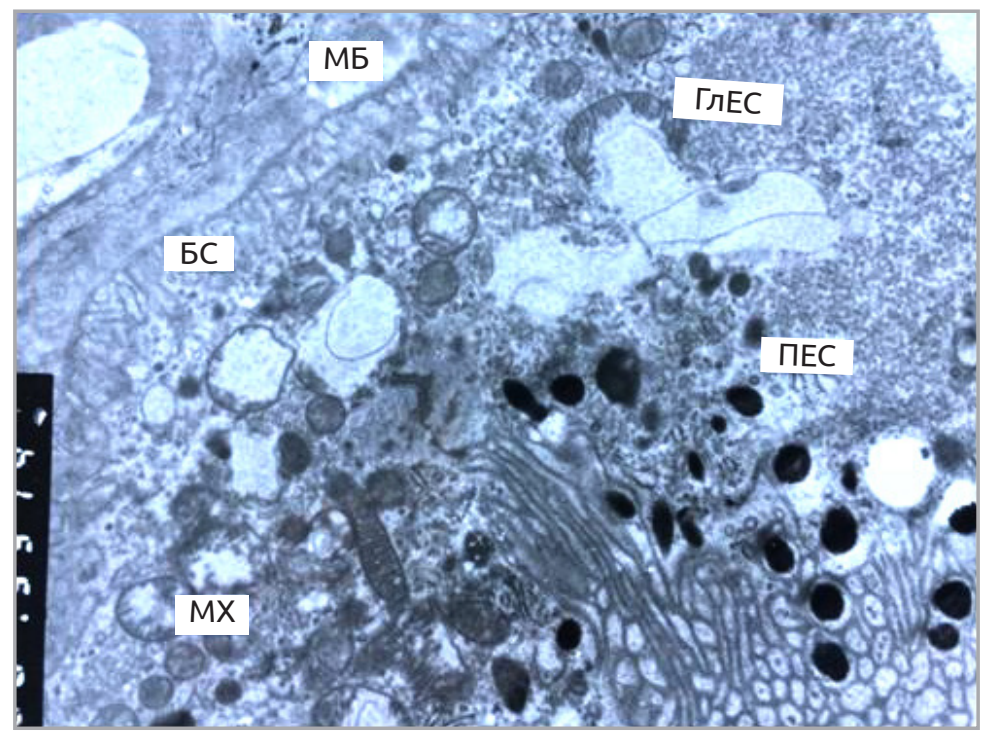

Рис. 3.Ультраструктура сітківки кроля після 10-денного застосування нейропротектора на фоні модельованого увеїту.

Фрагмент клітини пігментного епітелію. Базальна складчастість та апікальні мікроворсинки у нормальному стані. Мітохондрії з добре розвиненими щільноупакованими кристами, частина їх вакуолізована. Цитоплазма збагачена полісомами. Електронна мікрофотографія: $\times 8000$.

Примітка. МБ - мембрана Бруха, ПЕС - пігментний епітелій сітківки, БС - базальна складчастість, ГлЕС - гладка ендоплазматична сітка, MX-мітохондрії.

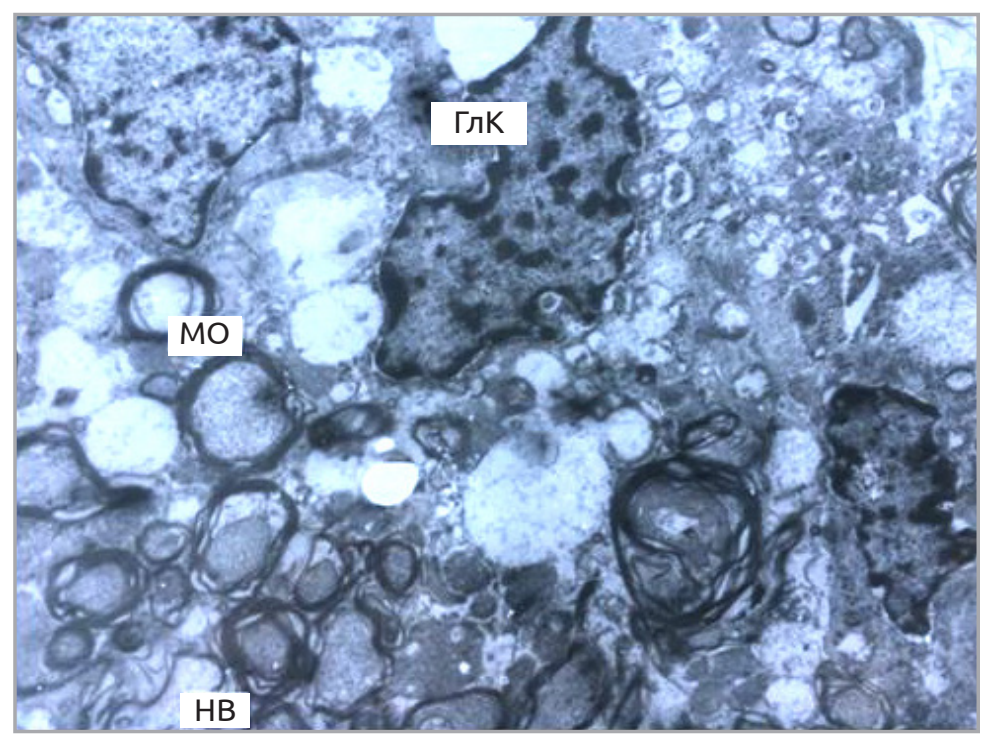

Рис. 4. Ультраструктура зорового нерва кроля після 10-денного застосування нейропротектора на фоні модельованого увеїту.

Ядра гліальних клітин із звивистою каріолемою та переважанням дифузного хроматину. Цитоплазма збагачена полісомами. Зберігається гідропія мембранних органел, локальне розшарування мієлінових оболонок. Електронна мікрофотографія: × 5000.

Примітка. ГлК - гліальна клітина, МО - мієлінова оболонка, НВ - нервові волокна. 
Огляди літератури, оригінальні дослідження, погляд на проблему, випадок з практики, короткі повідомлення

Аналіз матеріалу показав, що на фоні розвиненого модельованого увеїту деструктивні явища виникають і в нервових структурах. 3 огляду на те, що трофіка ПЕС та ЗСФК цілком залежить від стану ХK, саме в цій зоні були найбільш виражені альтеративні зміни. Більш глибокі шари сітківки виявилися ураженими менше. Застосування цитиколіну помітно активувало компенсаційно-відновні процеси, що проявлялось в ядерних змінах - звивиста форма, переважання дифузного хроматину, наявність ядерець; та цитоплазматичних - збільшення білковосинтезувальних органел та мітохондрій з розвиненими кристами. Проте повного відновлення структури у цей термін спостереження не відбувалось. Зберігалися осередки деструкції, локальні набрякові явища, пошкодження мієлінових оболонок.

Останнім часом з'явилися роботи, в яких доведена роль запальної природи у розвитку нейродегенеративних процесів. Ознаки запалення виявлені при хворобі Альцгеймера [11], при бічному аміотрофічному склерозі [18], при хворобі Паркінсона [12], при так званій темпорально-мезіальній епілепсії [34]. Крім того, в серії експериментальних робіт було продемонстровано, що індукція запалення в мозку лабораторних тварин може призводити до розвитку патоморфологічних і клінічних симптомів, аналогічнихтаким при відомихнейродегенеративних хворобах, зокрема хворобі Паркінсона, а використання протизапальних засобів, наприклад циклоспорину A, може зупинити процес нейродегенерації $[5,23,24]$. Також існують роботи, зокрема в нашому Інституті, що присвячені вивченню нейродегенерації при цукровому діабеті [8].

Тож постає питання - якщо при нейродегенеративних захворюваннях $є$ ознаки запалення, чи виникає нейродегенерація при запальному процесі. В ході нашого експерименту (модель неінфекційного увеїту) ми встановили, що запальний процес судинної оболонки супроводжується нейродегенеративними змінами в сітківці та зоровому нерві. Наші дані збігаються з результатами, отриманими при моделюванні увеоретиніту в мишей. У них моделювали увеоретиніт за допомогою міжфоторецепторного ретинолзв'язуючого протеїну та було отримано значне ураження зовнішніх сегментів фоторецептрів та нервових волокон [21]. Міжфоторецепторний ретинол-зв'язуючий протеїн - це головна розчинна частина міжфоторецепторного матриксу, який оточує зовнішні та внутрішні сегменти фоторецепторів [30]. Також $\epsilon$ робота з моделювання увеоретиніту на морських свинках із застосуванням S-антигену сітківки, в якій отримано селективне ураження зовнішніх шарів сітківки [17]. Моделювання увеоретинітів проводили за допомогою речовин, які виклика- ють імунну відповідь саме на компонент сітківки, тож зрозуміло що в сітківці повинні були розвинутись дегенеративні зміни. На відміну від цих робіт, ми для імунізації застосовували кінську сироватку, яка не має прямого імуногенного впливу на сітківку та її компоненти. Тому отримані нами нейродегенеративні зміни у сітківці й зоровому нерві ми розглядаємо саме як ускладнення переднього та середнього увеїту, а не результат прямого впливу на сітківку.

Препаратом для лікування цих змін ми обрали цитиколін, який активно вивчався як нейропротектор (Clark W.M. et al. 1997, 1999, 2001) у гострій стадії ішемічного інсульту. Були проведені декілька плацебо-контрольованих досліджень у Західній Європі та Японії з доказами покращення неврологічних функцій у хворих, які отримували цитиколін $[13,14,15]$.

Aronowski J. в 1996 р. досліджував дію цитиколіну в порівнянні з плацебо в експериментальній моделі інсульту в щурів, викликаній перев'язуванням на дві години правої середньої мозкової артерії. Гістологічне дослідження встановило, що в групі щурів, які отримували цитиколін, відновлювальні процеси у тканинах головного мозку були більш вираженими, ніж у групі тварин, що отримували плацебо [3, 10].

Жилюк В. І. із співавт. (2013) в експериментальному дослідженні з використанням цитиколіну в умовах гіперглікемії при моделюванні діабету встановили, що він сприяє активізації компенсаторно-адаптаційних процесів у нейрональних і гліальних клітинах, зменшенню порушень мієлінових нервових волокон, збільшенню щільності упаковки синаптичних пухирців та стабілізації структури пресинаптичної та постсинаптичної мембран, збільшенню щільності нейронів і ендотеліоцитів, що свідчить про високий терапевтичний потенціал цього лікувального засобу в даних умовах [4].

У наведених дослідженнях ми бачимо дані щодо активації компенсаторно-відновлювальних процесів головного мозку при отриманні цитиколіну, що також збігається з нашими даними.

Висновки. Неінфекційний увеїт, змодельований за допомогою кінської сироватки, в судинній та сітчастій оболонках викликає гідропічну дегенерацію ендотеліальних клітин ХК і клітин сітківки, особливо ПЕС, а також міжклітинний набряк у ділянці ФК і пошкодження та фрагментацію ЗСФК.

У зоровому нерві неінфекційний увеїт, змодельований за допомогою кінської сироватки, викликає значні деструктивні зміни як в нервових волокнах, зокрема, мієлінових оболонок, так і в гліальних клітинах, із пошкодженням їх плазмолем, а також осередковий міжклітинний набряк. 
Огляди літератури, оригінальні дослідження, погляд на проблему, випадок з практики, короткі повідомлення

Застосування нейропротектора на ранніх термінах (цитиколіну) при неінфекційному увеїті активує внутрішньоклітинні компенсаторні процеси в сітківці, зокрема, в ПЕС, що приводить до зменшення ознак гідропічної дегенерації та нормалізації ультраструктури клітин.

Застосування нейропротектора (цитиколіну) при неінфекційному увеїті сприяє активації метаболічних процесів у гліальних клітинах і аксоплазмі в $3 \mathrm{H}$.
Перспективи подальших досліджень. Плануємо в експерименті дослідити, чи відбуватимуться активні компенсаторні та метаболічні процеси в сітківці, хоріоідеї та зоровому нерві при більш тривалому використанні нейропротектора у кролів, на відміну від кролів, у яких нейропротектор не застосовуватиметься.

\section{ЛІТЕРАТУРА}

1. Тяжелое течение анкилозирующего спондилоартрита с дебютом в ювенильном периоде у пациентки с рецидивирующим увеитом / К. А. Гамаюнова, А. П. Ребров, Я. В. Галстян, Т. Г. Каменских // Архивъ внутренней медицины. - 2019. - № 9 (3). - С. 235-240.

2. Течение и исходы увеита у больных анкилозирующим спондилитом / А. А. Годзенко, А. Г. Бочкова, О. А. Румянцева [и др.] // Научн.-практ. ревматол. 2014. - № 52 (5). - С. 520-525.

3. Комплексная нейропротекция у больных с сосудистой патологией мозга / Е.В.Елисеев, И.В.Крюкова, С. А. Румянцева [и др.] // Междунар. невролог. журнал. - 2008. - 6 (22). - С. 109-113.

4. Ультраструктурная характеристика неокортекса крыс с аллоксановойгипергликимией в условиях применения цитиколина / В. И. Жилюк, В. И. Мамчур, И. В. Твердохле6, Н. С. Петрук // Морфология. - 2013. Т. 7, № 4. - С. 30-36.

5. Синдром паркинсонизма у молодых женщин, страдающих дефицитом миелопероксидазы фагоцитов / В. Е. Казмирчук, Д. В. Мальцев, Т. Н. Слободин, Ю. И. Головченко // Междунар. невролог. журнал. 2011. - №1 (39) . - С. 15-23.

6. Оценка нейропротекторного действия цитиколина при оптиконейропатиях различного генеза / Т. В. Качан, Л. Н. Марченко, А. А. Далидович [и др.] // Новости глаукомы. - 2017. - №. 1. - С. 55-58.

7. Эффективность цитиколина в комплексном лечении ЧАЗН различного генеза / С. М. Ким, Н. В. Коршунова, Е. М. Галкина, И. В. Пономарева // Практическая медицина. - 2016. - № 6 (98). - С. 62-65.

8. Мальцев Э. В. Новый диффернцированный поход к моделированию диабетической ретинопатиии / Э. В. Мальцев, А. В. Зборовская, А. Э. Дорохова // Точка Зрения. Восток-Запад. - 2016. - № 1. - С. 109-111.

9. Нейропротекторный эффект таблетированной формы цитиколина у пациентов с глаукомной оптиконейропатией / Л. Н. Марченко, Т. В. Качан, А. А. Далидович [и др.]//Офтальмология. Восточная Европа.-2019.T. 9. - № 4. - С. 554-561.

10. Aronowski J. Citicoline for treatment of experimental focal ischemia: histologic and behavioral outcome / J. Aronowski, R. Strong, J. C. Grotta // Neurol. Res. - 1996. Vol. 18. - P. 570-574.

11. Banks W. A. Immunotherapy and neuroimmunology in Alzheimer's disease: a perspective from the blood-brain barrier / W. A. Banks // Immunother. - 2010. - Vol. 2 (1). P. 1-3.
12. Bartels A. L. Neuroinflammation in the pathophysiology of Parkinson's disease: evidence from animal models to human in vivo studies with [11C]-PK11195 PET / A. L. Bartels, K. L. Leenders // Mov. Disord. - 2007. Vol. 2 (13). - P. 1852-1856.

13. A randomized dose-response trial of citicoline in acute ischemic stroke patients. Citicoline Stroke Study Group / W. M. Clark, S. J. Warach, L. C. Pettigrew [et al.] // Neurol. - 1997. - Vol. 49. - P. 671-678.

14. A randomized efficacy trial of citicoline in patients with acute ischemic stroke / W. M. Clark, B. J. Williams, K. A. Selzer [et al.] // Stroke. - 1999. - Vol. 30. P. 2592-2597.

15. Citicoline Stroke Study Group. A phase III randomized efficacy trial of $2000 \mathrm{mg}$ citicoline in acute ischemic stroke patients / W. M. Clark, L. R. Wechsler, L. A. Sabounjian, U. E. Schwiderski // Neurol. - 2001. - Vol. 57. P. 1595-1602.

16. Temperature of the ocular surface in the projection of the ciliary body in rabbits / O. Dorokhova, O. Zborovska, O. S. Zadorozhnyy, M. Guanjun // J. Ophthalmol. (Ukraine). - 2020. - No. 2 (493). - P. 65-69.

17. Forrester J. V. Ultrastructural pathology of S-antigen uveoretinitis / J. V. Forrester, G. M. Borthwick, P. G. McMenamin // Invest. Ophthalmol. Vis. Sci. - 1985. - Vol. 26 (9). - P. 1281-1292.

18. PATH45 Cytoskeletal and inflammatory protein biomarkers for amyotrophic lateral sclerosis / J. Ganesalingam, D. Lacomis, J. Lustgarten [et al.] // J. Neurol. Neurosurg. Psychiatry. - 2010. - Vol. 81 (11). - P. 20.

19. Goldstein $H$. The reported demography and causes of blindness throughout the world / H. Goldstein // Adv. Ophthalmol. - 1980. - Vol. 40. - P. 1-99.

20. Gritz D. C. Incidence and prevalence of uveitis in Northern California; the Northern California Epidemiology of Uveitis Study / D. C. Gritz, I. G. Wong // Ophthalmology.2004. - Vol. 111 (3). - P. 491-500.

21. Hankey D. J. R. Interphotoreceptor retinoid binding protein peptide-induced uveitis in B10.RIII mice: characterization of disease parameters and immunomodulation / D. J. R. Hankey, S. L. Lightman, D. Baker // Experim. Eye Res. - 2001. - Vol. 72 (3). - P. 341-350.

22. Hyung $C$. Etiology and treatment of the inflammatory causes of cystoid macular edema / C. Hyung, M. Assumpta // J. Inflamm. Res. - 2009. - Vol. 2. - P. 37-43.

23. Initial cyclosporin A but not glucocorticoid treatment promotes recovery of striatal dopamine concentration in 6-hydroxydopamine lesioned mice / K. Matsuura, 
Огляди літератури, оригінальні дослідження, погляд на H. Kabuto, H. Makino, N. Ogawa // Neurosci. Lett. - 1997. Vol. 230 (3). - P. 191-194.

24. Matsuura K. Cyclosporin A attenuates the decrease in tyrosine hydroxylase immunoreactivity in nigrostriatal dopaminergic neurons and in striatal dopamine content in rats with intrastriatal injection of 6-hydroxydopamine / K. Matsuura, H. Makino, N. Ogawa // Exp. Neurol. - 1997. - Vol. 146 (2). - P. 526-535.

25. Epidemiology of endogenous uveitis in northeastern Italy. Analysis of 655 new cases / A. Mercanti, B. Parolini, A. Bonora [et al.] // Acta Ophthalmol. Scand. 2001. - Vol. 79 (1). - P. 64-68.

26. Neuroprotective effect of citicoline against KAinduced neurotoxicity in the rat retina / C. H. Park, Y. S. Kim, H. S. Noh [et al.] // Exp. Eye Res. - 2005. - Vol. 81. P. 350-358.

27. Action of citicoline on rat retinal expression of extracellular-signal-regulated kinase (ERK1/2) / C. H. Park, Y. S. Kim, E. W. Cheon [et al.] // Brain Res. - 2006. - Vol. 81. P. 203-210.

28. Posterior segment ocular manifestations in patients with HLA-B27-associated uveitis / A. Rodriguez, Y. A. Akova, M. Pedroza-Seres, C. S. Foster // Ophthalmo-

\section{REFERENCES}

1.Gamayunova, K.A., Rebrov, A.P., Galstyan, Ya.V., \& Kamenskikh, T.G. (2019). Tyazheloye techeniye ankiloziruyushchego spondiloartrita s debyutom v yuvenilnom periode u patsiyentki s retsidiviruyushchim uveitom [Severe course of ankylosing spondylitis with debut in the juvenile period in a patient with recurrent uveitis]. Arkhiv vnutrenney meditsiny - Archive of Internal Medicine, 9 (3), 235-240 [in Russian].

2. Godzenko, A.A., Bochkova, A.G., Rumyantseva, O.A., Razumova, I.Yu., Badokin, V.V., \& Erdes, Sh.F. (2014). Techeniye i iskhody uveita u bolnykh ankiloziruyushchim spondilitom [The course and outcomes of uveitis in patients with ankylosing spondylitis]. Nauchn. prakt. revmatol. - Sci. Pract. Rheumatol., 52 (5), 520-525. Retrieved from: https:// doi.org/10.14412/1995-4484-2014-520-525.

3. Yeliseyev, Ye.V., Kryukova, I.V., Rumyantseva, S.A., Svishcheva, S.P., Silina, Ye.V., \& Shuchalin, O.G. (2008). Kompleksnaya neyroprotektsiya u bolnykh s sosudistoy patologiyey mozga [Complex neuroprotection in patients with cerebrovascular pathology]. Mezhdunar. Nevrol. Zhurnal - Int. Neurol. J., 6 (22), 109-113 [in Russian].

4. Zhilyuk, V.I., Mamchur, V.I., Tverdokhleb, I.V., \& Petruk, N.S. (2013). Ultrastrukturnaya kharakteristika neokorteksa krys s alloksanovoygiperglikimiyey $v$ usloviyakh primeneniya tsitikolina [Ultrastructural characteristics of the neocortex of rats with alloxan hyperglycemia under conditions of citicoline use]. Morphologia-Morphology, 7, 4, 30-36 [in Russian].

5. Kazmirchuk, V.Ye., Maltsev, D.V., Slobodin, T.N., \& Golovchenko, Yu.l. (2011). Sindrom parkinsonizma u molodykh zhenshchin, stradayushchikh defitsitom miyeloperoksidazy fagotsitov [Parkinson's syndrome in young women suffering from phagocyte myeloperoxidase deficiency]. Mezhdunar. Nevrol. Zhurnal - Int. Neurol. J., 1 (39), 15-23 [in Ukrainian]. logy. - 1994. - Vol. 101 (7). - P. 1267-1274.

29. Rothova A. Inflammatory cystoid macular edema / A. Rothova // Curr. Opin. Ophthalmol. - 2007. - Vol. 18. P. 487-492.

30. Retina / S. Ryan, C. Wilkinson, A. Schachat [et al.]; S. V. Sadd ed. - 5th edn. - Saunders, 2012. - 2564 p.

31. Saari K. M. Epidemiology of endogenous uveitis in south-western Finland / K. M. Saari, T. Palvonsalo-Hietanen, H. Vaahtoranta-Lehtonenetal // Acta Ophthalmol. Scand. - 1995. - Vol. 73 (4). - P. 345-349.

32. Macular thickening in acute anterior uveitis / A. Traill, R. Stawell, A. Hall, E. Zamir // Ophthalmol. - 2007. Vol. 114 (2). - P. 402

33. Uy H. S. HLA-B27 associated uveitis and cystoids macular edema / H. S. Uy, W. G. Christen, C. S. Foster // Ocul. Immunol. Inflam. - 2001. - Vol. 9 (3). - P. 177-183.

34. Vezzani A. Brain inflammation in epilepsy; experimental and clinical evidence / A. Vezzani, T. Granata // Epilepsia. - 2005. - Vol. 46 (11). - P. 1724-1743.

35. Wexler A. Bilateral macular thickening in mild unilateral anterior uveitis: is HLA-B27 involved / A. Wexler, T. Sand, T. B. Elsås // BMC Ophthalmol. - 2012. - No. 12 (1). P. 30-40.

6. Kachan, T.V., Marchenko, L.N., Dalidovich, A.A. Fedulov, A.S., Dzhumova, M.F., Dzhumova, A.A., \& Abubakar, B.U. (2017). Otsenka neyroprotektornogo deystviya tsitikolina pri optikoneyropatiyakh razlichnogo geneza [Assessment of the neuroprotective action of citicoline in optic neuropathies of various origins]. Novosti glaukomy Glaucoma News, 1, 55-58 [in Russian].

7. Kim, S.M., Korshunova, N.V., Galkina, Ye.M., \& Ponomareva, I.V. (2016). Effektivnost tsitikolina v kompleksnom lechenii CHAZN razlichnogo geneza [The effectiveness of citicoline in the complex treatment of PAD of various genesis]. Prakticheskaya meditsina - Practical Medicine, 6 (98), 62-65 [in Russian].

8. Maltsev, E.V., Zborovskaya, A.V., \& Dorokhova, A.E. (2016). Novyy differntsirovannyy pokhod k modelirovaniyu diabeticheskoy retinopatiii [A new differentiated approach to modeling diabetic retinopathy]. Tochka Zreniya. VostokZapad - Point of View. East-West, 1, 109-111 [in Russian].

9. Marchenko, L.N., Kachan, T.V., Dalidovich, A.A., Mushtina, T.A., \& Dis, O.V. (2019). Neyroprotektornyy effekt tabletirovannoy formy tsitikolina u patsiyentov $s$ glaukomnoy optikoneyropatiyey [Neuroprotective effect of citicoline tablets in patients with glaucoma opticneuropathy]. Oftalmologiya. Vostochnaya Evropa - Ophthalmology. East. Eur., 9, 4, 554-561 [in Russian].

10. Aronowski, J., Strong, R., \& Grotta, J.C. (1996). Citicoline for treatment of experimental focal ischemia: histologic and behavioral outcome. Neurol. Res., 18, 570-574.

11. Banks, W.A. (2010). Immunotherapy and neuroimmunology in Alzheimer's disease: a perspective from the blood-brain barrier. Immunother., 2 (1), 1-3.

12. Bartels, A.L., \& Leenders, K.L. (2007). Neuroinflammation in the pathophysiology of Parkinson's disease: evidence from animal models to human in vivo studies with [11C]-PK11195 PET. Mov. Disord., 22 (13), 1852-1856. 
Огляди літератури, оригінальні дослідження, погляд на проблему, випадок з практики, короткі повідомлення

13. Clark, W.M., Warach, S.J., Pettigrew, L.C., Gammans, R.E., \& Sabounjian, L.A. (1997). A randomized doseresponse trial of citicoline in acute ischemic stroke patients. Citicoline Stroke Study Group. Neurol., 49, 671-678.

14. Clark, W.M., Williams, B.J., Selzer, K.A., Zweifler, R.M., Sabounjian, L.A., \& Gammans, R.E. (1999). A randomized efficacy trial of citicoline in patients with acute ischemic stroke. Stroke, 30, 2592-2597.

15. Clark, W.M., Wechsler, L.R., Sabounjian, L.A., \& Schwiderski, U.E. (2001). A phase III randomized efficacy trial of $2000 \mathrm{mg}$ citicoline in acute ischemic stroke patients. Neurol., 57, 1595-1602.

16. Dorokhova, O., Zborovska, O., Zadorozhnyy, O.S., \& Guanjun, M. (2020). Temperature of the ocular surface in the projection of the ciliary body in rabbits. J. Ophthalmol. (Ukraine), 2 (493), 65-69.

17. Forrester, J.V., Borthwick, G.M., \& McMenamin, P.G. (1985). Ultrastructural pathology of S-antigen uveoretinitis. Invest. Ophthalmol. Vis. Sci., 26 (9), 1281-1292.

18. Ganesalingam, J., Lacomis, D., Lustgarten, J., Shaw, C.E., Bowser, R., \& An, J. (2010). PATH45 Cytoskeletal and inflammatory protein biomarkers for amyotrophic lateral sclerosis. J. Neurol. Neurosurg. Psychiatry, 81 (11), 20.

19. Goldstein, H. (1980). The reported demography and causes of blindness throughout the world. Adv. Ophthalmol., 40, 1-99.

20. Gritz, D.C., \& Wong, I.G. (2004). Incidence and prevalence of uveitis in Northern California; the Northern California Epidemiology of Uveitis Study. Ophthalmol., 111 (3) 491-500. hhtp://dx.doi.org/10.1016/j.ophtha.2003.06.014.

21. Hankey, D.J.R., Lightman, S.L., \& Baker, D. (2001). Interphotoreceptor retinoid binding protein peptide-induced uveitis in B10.RIII mice: characterization of disease parameters and immunomodulation. Experim. Eye Res., 72 (3), 341-350.

22. Hyung, C., \& Assumpta, M. (2009). Etiology and treatment of the inflammatory causes of cystoid macular edema. J. Inflamm. Res., 2, 37-43.

23. Matsuura, K., Kabuto, H., Makino, H., \& Ogawa, N. (1997). Initial cyclosporin A but not glucocorticoid treatment promotes recovery of striatal dopamine concentration in 6-hydroxydopamine lesioned mice. Neurosci. Lett., 230 (3), 191-194.

24. Matsuura, K., Makino, H., \& Ogawa, N. (1997). Cyclosporin $\mathrm{A}$ attenuates the decrease in tyrosine hydroxylase immunoreactivity in nigrostriatal dopaminergic neurons and in striatal dopamine content in rats with intrastriatal injection of 6-hydroxydopamine. Exp. Neurol., 146 (2), 526-535.

25. Mercanti, A., Parolini, B., Bonora, A., Lequaglie, Q., \& Tomazzoli, L. (2001). Epidemiology of endogenous uveitis in north-eastern Italy. Analysis of 655 new cases. Acta Ophthalmol. Scand., 79 (1), 64-68. DOI:10.1034/ j.1600-0420.2001.0790010 64.x.

26. Park, C.H., Kim, Y.S., Noh, H.S., Cheon, E.W. Yang, Y.A., Yoo, J.M., ..., \& Cho, G.J. (2005). Neuroprotective effect of citicoline against KA-induced neurotoxicity in the rat retina. Exp. Eye Res., 81, 350-358. DOI: 10.1016/ j.exer.2005.02.007.

27. Park, C.H., Kim, Y.S., Cheon, E.W., Noh, H.S. Cho, C.H., Chung, I.Y., ... \& Gyeong, J.C. (2006). Action of citicoline on rat retinal expression of extracellular-signal-regulated kinase (ERK1/2). Brain Res., 81, 203-210. DOI:10.1016/j. brainres.2005.12.128.

28. Rodriguez, A., Akova, Y.A., Pedroza-Seres, M., \& Foster, C.S. (1994). Posterior segment ocular manifestations in patients with HLA-B27-associated uveitis. Ophthalmol., 101 (7), 1267-1274.

29. Rothova, A. (2007). Inflammatory cystoid macular edema. Curr. Opin. Ophthalmol., 18, 487-492.

30. Ryan, S., Wilkinson, C., Schachat, A., Hinton, D., \& Wiedemann, P. (2012). Retina. S.V. Sadd Ed. 5th Edn. Saunders.

31. Saari, K.M., Palvonsalo-Hietanen, T., \& Vaahtoranta-Lehtonenetal, H. (1995). Epidemiology of endogenous uveitis in south-western Finland. Acta Ophthalmol. Scand., 73 (4), 345-349. Retrieved from: http://dx.doi. org/10.1111/j.1600-0420.1995.tb00040.x.

32. Traill, A., Stawell, R., Hall, A., \& Zamir, E. (2007). Thickening in acute anterior uveitis. Ophthalmol., 114 (2), 402. Retrieved from: https://doi.org/10.1016/j. ophtha.2006.07.028.

33. Uy, H.S., Christen, W.G., \& Foster, C.S. (2001) HLA-B27 associated uveitis and cystoids macular edema. Ocul. Immunol. Inflam., 9 (3), 177-183.

34. Vezzani, A., \& Granata, T. (2005). Brain inflammation in epilepsy; experimental and clinical evidence. Epilepsia, 46 (11), 1724-1743.

35. Wexler, A., Sand, T., \& Elsås, T.B. (2012). Bilateral macular thickening in mild unilateral anterior uveitis: is HLA-B27 involved. BMC Ophthalmol., 12 (1), 30-40. DOI:10.1186/1471-2415-12-30.

\title{
УЛЬТРАСТРУКТУРНОЕ СОСТОЯНИЕ СЕТЧАТКИ И ЗРИТЕЛЬНОГО НЕРВА В ЭКСПЕРИМЕНТЕ НЕИНФЕКЦИОННОГО ПЕРЕДНЕГО И СРЕДНЕГО УВЕИТА НА КРОЛИКАХ БЕЗ ЛЕЧЕНИЯ И ПРИ ИСПОЛЬЗОВАНИИ НЕЙРОПРОТЕКТОРА
}

\section{๑А. В. Зборовская, Н. И. Молчанюк, А. Э. Дорохова, И. С. Горянова}

\author{
ГУ «Институт глазных болезней и тканевой терапии имени В. П. Филатова АМн Украины», Одесса
}

PEЗЮМЕ. В литературе отсутствуют сведения о нейродегенеративных процессах в сетчатке и зрительном нерве при передних и средних увеитах.

Цель - провести сравнительное ультраструктурное исследование $3 \mathrm{H}$, сетчатой и сосудистой оболочек глаза при неинфекционном переднем и среднем увеите в эксперименте.

Материал и методы. Эксперимент проведен на 4 кроликах: 1 група - 2 кролика (без лечения), 2 група 2 кролика (нейропротектор). Изучалась ультраструктура хориокапилляров (ХК), сетчатки и зрительных нервов (3Н) кроликов через 10 суток. 
Огляди літератури, оригінальні дослідження, погляд на проблему, випадок з практики, короткі повідомлення

Результаты. В 1 группе в 3Н выявлены глубокие деструктивные процессы в нервных волокнах, миелиновой оболочке, в глиальных клетках с разрушением их плазмолеммы, а также очаговый межклеточный отек. В сосудистой и сетчатой оболочках выявлены гидропическая дегенерация эндотелиальных клеток ХК и клеток сетчатки, особенно ПЭС, а также межклеточный отек в области ФК. Во 2 группе в ЗН деформация миелиновых облочек и явления отека в аксоплазме встречаются в меньшей мере и в меньшем количестве НВ. В аксоплазме большинства НВ митохондрии и другие органеллы имели нормальную ультраструктуру. Наиболее сохранными оказались НВ мелкого калибра. В слое ХК преобладали ЕК с признаками компенсационно-восстановительных процессов. Наряду с этим часть ЕК ХК оставались в состоянии отека.

Выводы. Передний и средний неинфекционный увеит, моделируемый с помощью лошадиной сыворотки, на ранних сроках вызывает нейродегенеративные изменения в сетчатой оболочке и ЗН, а при использовании нейропротектора (на протяжении 10 дней) явления нейродегенерации выражены в меньшей мере.

КЛючЕВЫЕ СЛОВА: неинфекционный увеит; нейродегенерация; нейропротектор.

\title{
ULTRASTRUCTURAL STATE OF THE RETINA AND OPTIC NERVE IN THE EXPERIMENTAL NON-INFECTIOUS ANTERIOR AND INTERMEDIATE UVEITIS IN RABBITS WITHOUT TREATMENT AND WITH NEUROPROTECTIVE DRUG
}

\section{O. V. Zborovska, N. I. Molchanyuk, O. E. Dorokhova, I. S. Horyanova}

\author{
Institute of Diseases and Tissue Therapy V. Filatov National Academy of Medical Sciences of Ukraine, Odesa
}

SUMMARY. There is no information in the literature on neurodegenerative processes in the retina and optic nerve in anterior and middle uveitis.

The aim - to conduct a comparative ultrastructural study of the optic nerve, the retina and the choroid with noninfectious anterior and intermeidiate uveitis in the experiment.

Material and Methods. The experiment was carried out on 4 rabbits: group 1 - 2 rabbits (without treatment), group 2 - 2 rabbits (got neuroprotective drug). The ultrastructure of the choriocapillaries (CC), retina and optic nerves (ON) were studied after 10 days.

Results. In group 1, ON revealed deep destructive processes in nerve fibers, myelin sheath, in glial cells with destruction by their plasmols and focal intercellular edema. In the choroid and retina, hydropic degeneration of CC endothelial cells and retinal cells, especially PRE and intercellular edema in the fotoreceptor cells area were revealed. In group 2 in the ON, the deformation of the myelin sheaths and the phenomena of edema in the axoplasm are found to a lesser extent and in a smaller amount of nerve fibers. In the axoplasm of most nerve fibers, mitochondria and other organelles had normal ultrastructure. Small caliber nerve fibers were found to be the most intact. In the CC layer, endothelial cells with signs of compensation and recovery processes prevailed. Along with this, a part of the CC endothelial cells remained in a state of edema.

Conclusions. Anterior and middle non-infectious uveitis, modeled with horse serum, in the early stages causes neurodegenerative changes in the retina and $\mathrm{ON}$, and under using a neuroprotective drug (for 10 days), the phenomena of neurodegeneration are less pronounced.

KEY WORDS: non-infectious uveitis; neurodegeneration; neuroprotector.

Отримано 22.08.2020 